\title{
PENGARUH LABA, ARUS KAS BEBAS DAN PEMBAYARAN DIVIDEN KAS SEBELUMNYA TERHADAP DIVIDEN KAS YANG DITERIMA OLEH PEMEGANG SAHAM \\ ( Studi Pada Perusahaan Manufaktur Terdaftar di Bursa Efek Indonesia)
}

\author{
Oleh: \\ Jen Surya \\ (Universitas Abulyatama Aceh) \\ Ridha Ramli \\ (PT Lafarge Cement Indonesia)
}

\begin{abstract}
The aimed of this research is to investigate The influence of earning, free cash flow and divident of cash last year to divident of cash, and the subject are manufacture emitent that listed on Indonesian Stock Exchange (ISE). The result of research show the earning, free cash flow and divident of cash last year have influence to divident of cash simultaneously positive. Eventhought partially earning, free cash flow less significat influnce to divident of cash, but last year divident of cash has positive significant to cash of divident on manufacture emitent listed on Indonesian stock exchange
\end{abstract}

Keywords: earning, free cash flow, divident last year, and divident of cash.

\section{Latar Belakang}

Aktivitas investasi merupakan aktivitas yang dihadapkan pada berbagai macam risiko dan ketidakpastian yang seringkali sulit diprediksikan oleh para investor. Investor mengharapkan untuk mendapatkan tingkat kembalian (return) baik berupa dividen maupun capital gain tidak didasarkan pada kebijakan manajemen (intern) perusahaan, tetapi didasarkan pada hasil atau kinerja yang telah dicapai oleh perusahaan yang tercermin dalam laporan keuangan yang dipublikasikan. Sejauh ini laporan keuangan, khususnya neraca dan laporan laba/rugi masih diyakini sebagai alat yang andal bagi para pemakainya untuk mengurangi risiko ketidakpastian dalam pengambilan keputusankeputusan ekonomi. Kebijakan apapun yang ditempuh oleh manajemen perusahaan, bagi investor tidak terlalu dipertimbangkan, karena kebijakan manajemen hanya dapat diketahui oleh pihak intern perusahaan

Keputusan untuk menentukan berapa banyak dividen yang harus dibagikan kepada para investor disebut kebijakan dividen (dividend policy). Di sisi lain perusahaan dihadapkan dalam berbagai macam kebijakan, antara lain : perlunya menahan sebagian laba untuk re-investasi yang mungkin lebih menguntungkan, kebutuhan dana perusahaan, likuiditas perusahaan, sifat pemegang saham, target tertentu yang berhubungan dengan rasio pembayaran dividen dan faktor lain yang berhubungan dengan kebijakan dividen.

Dividen memiliki hubungan yang positif dengan laba, hal ini terlihat dimana umumnya perusahaan akan menaikkan dividen billa terjadi peningkatan laba, Beberapa peneliti antara lain Litner (1956) mengemukakan bahwa perusahaan hanya akan menaikkan dividen bila manajemen berkeyakinan bahwa laba perusahaan akan naik. Dividen umumnya dapat dibagikan kepada pemegang saham oleh perusahaan bila laporan laba rugi menunjukkan adanya perolehan laba, dan laba yang dibagikan kepada pemegang saham berupa dividen bersumber dari laba bersih. 
Laba bersih (net income) adalah laba yang diperoleh perusahaan setelah dikurangi semua biaya yang terjadi dalam aktivitas perusahan termasuk pajak. Swasta (1997 : 30) "Laba bersih dapat diperoleh dari seluruh penghasilan dikurangi seluruh biaya. Besarnya laba bersih yang dapat diperoleh akan menjadi ukuran sukses bagi suatu perusahaan". Selain laba, investor juga menggunakan informasi arus kas sebagai ukuran kinerja perusahaan. Informasi pada arus kas memungkinkan pengguna laporan untuk melihat keadaan kemampuan perusahaan menghasilkan kas. Informasi tersebut juga dapat meningkatkan daya banding laporan kinerja operasi perusahaan karena laporan ini meniadakan perlakuan akuntansi yang berbeda terhadap transaksi dan peristiwa yang sama (Elizabeth,2000).

Pernyataan Standar Akuntansi Keuangan (PSAK) No. 2 yang menyatakan bahwa perusahaan harus menyusun laporan arus kas dan menyajikan laporan tersebut sebagai bagian yang tak terpisahkan (integral) dari laporan keuangan untuk setiap periode penyajian laporan keuangan. Arus kas bebas merupakan laba operasi setelah pajak dikurangi investasi atas modal kerja, properti, perkebunan peralatan dan aset lainnya, "Free cash flow as equal to the after tax operating earnings of a company plus noncash charges less investment in working capital, property, plant and equipment, and other assets (Copeland et al., 1991)." Jelaslah bahwa arus kas operasi yang diperuntukkan untuk pembayaran dividen kas adalah arus kas bebas, dimana arus kas bebas merupakan arus kas yang merupakan sisa dari pengeluaran kas yang dikeluarkan untuk modal kerja dan asset.

Kebijakan dividen kas sebuah perusahaan memiliki dampak penting bagi banyak pihak yang terlibat di masyarakat (Suharli, 2004). Bagi para pemegang saham atau investor, dividen kas merupakan tingkat pengembalian investasi mereka berupa kepemilikan saham yang diterbitkan perusahaan lain. Bagi pihak manajemen, dividen kas merupakan arus kas keluar yang mengurangi kas perusahaan. Oleh karenanya kesempatan untuk melakukan investasi dengan kas yang dibagikan sebagai dividen tersebut menjadi berkurang. Bagi kreditor, dividen kas dapat menjadi signal mengenai kecukupan kas perusahaan untuk membayar bunga atau bahkan melunasi pokok pinjaman. Kebijakan dividen kas yang cenderung membayarkan dividen dalam jumlah relatif besar akan mampu memotivasi pemerhati untuk membeli saham perusahaan. Perusahaan yang memiliki kemampuan membayar dividen diasumsikan masyarakat sebagai perusahaan yang menguntungkan.

Pembayaran dividen yang stabil umumnya akan mempertimbangkan dividen sebelumnya dilakukan untuk menjaga kepercayaan investor, sebagaimana dinyatakan Warren and Reeve (2004:515) "How ever, many corporations try to maintain a stable dividend record in order to make their stock attractive to investor". Stabilitas pembayaran dividen perlu dilakukan untuk mengantisipasi terjadinya sentimen pasar, sehingga bila perusahaan tidak mampu menjaga stabilitas pembagian dividen atau sama sekali tidak membayarkannya maka oleh pasar perusahaan biasanya dianggap dalam keadaan pailit.

Penelitian ini dilakukan pada emiten manufaktur di Bursa Efek Indonesia (BEI) yang memiliki laba, arus kas operasi, arus kas bebas dan pernah melakukan pembayaran dividen kas tahun sebelumnya. Alasan pemilihan emiten manufaktur sebagai unit analisis penelitian ini didasarkan pada emiten manufaktur merupakan kelompok industri yang terbesar jumlahnya di Bursa Efek Indonesia (Indonesian Stock Exchange,2006). 


\section{Rumusan Masalah}

Berdasarkan judul penelitian ini, penulis merumuskan masalah sebagai berikut: Bagaimana laba, arus kas bebas, dan dividen kas sebelumnya, baik secara parsial maupun secara simultan berpengaruh terhadap dividen kas pada emiten manufaktur di Bursa Efek Indonesia.

\section{Kerangka Pemikiran}

Laba atau earnigs dihasilkan oleh proses akuntansi dan disajikan dalam laporan laba rugi. Generally accepted accounting principle (GAAP) menyatakan bahwa pengakuan pendapatan terjadi pada saat transfer of title, tanpa memperdulikan apakah perusahaan sudah atau belum menerima pembayaran tunai (accrual basis). Biaya yang berkaitan langsung dengan pendapatan akan diakui pada periode yang sama dengan pengakuan pendapatan. Biaya lain yang tidak berkaitan langsung dengan pendapatan akan diakui pada periode terjadinya. Pandangan lain menyebutkan bahwa; earnings merupakan suatu ukuran berapa besar harta yang masuk (pendapatan dan keuntungan) melebihi harta yang keluar (beban dan kerugian) suatu perusahaan (Scroeder and Clarck, 1998:131). Dari apa yang disampaikan oleh Clark dapat dikatakan bahwa earnings adalah laba, namun Wallace (1997:594) menyatakan laba adalah net income hal ini terlihat dari defenisi yang disampaikan Wallace yang menyatakan bahwa net income merupakan pengurangan beban (kerugian) terhadap pendapatan (keuntungan) dari semua sumber.

Income memiliki beberapa konsep, Hendriksen \& Breda (1992:338) mengklasifikasikan konsep income berdasarkan penerima income yaitu konsep value added, konsep Enterprise Net Income, Net Income to Investor, Net Income to Shareholders, dan Net Income to Residual Equity Holders. Dari semua konsep tersebut yang dimaksudkan dalam penelitian ini adalah Net Income to shareholders (laba bersih bagi pemegang saham).

Konsep laba bersih kepada pemegang saham (Net Income to Shareholders) merupakan pandangan yang paling banyak dipakai. Konsep ini menyatakan bahwa Net Income merupakan pengembalian (return) kepada pemilik perusahaan sebagai hasil investasi mereka pada suatu perusahaan, baik pemilik perusahaan dalam artian sebagai pemilik saham preferen maupun pemilik saham biasa.

Banyak literatur mendefenisikan Arus kas bebas (free cash flow). Secara umum arus kas bebas merupakan arus kas yang diperoleh dari operasi perusahaan yang bebas setelah perusahaan menginvestasikan kembali pada aktiva lain. Penman (2001:111) menyatakan bahwa "Called free cash flow because it is the part of the cash from operation that is free after the firm reinvests in new assest". Brigham dan Daves (2004:205) juga menggambarkan arus kas bebas adalah "Free cash flow is the cash actually available for distribution to investor after the company has made all the investment in fixed assets and working capitals necessary to sustain on going operation".

Arus kas bebas diperoleh dari arus kas operasi dikurangi arus kas investasi, Penman (2001:112) menyatakan bahwa "Free cash flow is cash flow from operation which is generated by investment less cash used to make investment. Free cash flow is cash from operation less than cash investments". Dari apa yang dikemukakan Penman tersebut dapat dikatakan bahwa arus kas bebas merupakan arus kas yang tersedia bagi investor, nilai perusahaan sangat tergantung pada harapan arus kas bebas dimasa datang. Oleh karena itu bagi manajer cara meningkatkan nilai perusahaan adalah dengan cara meningkatkan arus kas bebas (Brigham dan Daves, 2004: 204,205)

Manajer perusahaan dengan arus kas bebas yang relatif besar dapat meningkatkan kesejahteraan pemegang saham melalui peningkatan pembayaran dividen atau membeli kembali saham (Jensen,1986 dalam Arfan, 2006:56). Untuk itu arus kas bebas dapat 
dijadikan sebagai indikator yang baik untuk kinerja operasi perusahaan. Brigham dan Daves (2004:206) menyebutkan ada lima kegunaan arus kas bebas (1) membayar bunga kepada kreditor, (2) membayar pokok utang kepada kreditor, (3) membayar dividen kepada pemegang saham, (4) membeli kembali saham dari pemegang saham, dan (5) membeli surat-surat berharga (marketable securities) dan aset non operasi lainnya.

Laba yang diperoleh perusahaan dari usahanya tidak semua akan dibagikan kepada pemegang saham. Laba yang tidak dibagikan perusahaan disebut retained earnings. Laba yang diperoleh perusahaan pada dasarnya dapat diinvestasikan kembali sebagai penambahan aktiva untuk kegiatan operasional, membeli surat berharga, melunasi hutang, atau membagikannya kepada pemegang saham (lebih dikenal dengan dividen). Dividen adalah pembagian laba kepada para pemegang saham perusahaan sebanding dengan jumlah saham yang dipegang oleh masing-masing pemilik (Smith and Skousen, 1995:155). Dividen ada dua macam yaitu dividen kas dan dividen saham. Sebagaimana dinyatakan oleh Warren and Reeve (2004:515) "A cash distribution of earnings by a corporation to its shareholder is called a cash dividend, and a distribution of shares of stock to stockholder is called stock dividend".

Bagi investor untuk meyakini bahwa mereka akan memperoleh deviden adalah biasanya dengan adanya pengumuman pembagian deviden oleh pihak manajemen yang didasari dari hasil rapat umum pemegang saham (RUPS). Warren and Reeve (2004:515) menyatakan "a large amount of retained earnings does not always mean that a corporation is able to pay dividends. The balance of the cash and retained earnings account are often unrelated. Thus a large retained earnings account does not mean that there is cash available to pay dividend".

Jadi investor mengetahui jika mereka akan memperoleh dividen dengan adanya pengumuman resmi manajemen tentang pembagian dividen. Dividen biasanya dibagikan secara semesteran ataupun secara tahunan. Warren and Reeve (2004:515) menyatakan bahwa "Although dividends may be paid once a year or semiannually, most corporation pay dividends quarterly. In years of high profits, a corporation may declare a special extra dividend". Biasanya pengumuman pembagian dividen ini dapat kita lihat pada surat kabar dan maupun penyedia jasa investasi, dan ini akan mengurangi laba ditahan. Sebagaimana dinyatakan Warren and Reeve (2004:515) "The declaration of dividend reduces the retained earnings of the corporation".

Dividen merupakan laba yang diperoleh perusahaan dan dibagikan kepada pemegang saham atau modal. Untuk Penelitian hubungan laba dengan dividen dilakukan Lipe (1990) yang menemukan bahwa laba memiliki hubungan yang signifikan terhadap dividen, dimana dengan informasi laba bersih yang diperoleh akan dapat menentukan besaran dividen yang akan dibagikan atau diperoleh. Sedangkan Surya (2007) menguji pengaruh laba terhadap dividen, dan hasil uji menemukan bahwa laba berpengaruh terhadap dividen kas.

Umumnya pembagian laba didasarkan atas jumlah saham yang dimiliki perusahaan, pembagian laba yang didasarkan atas jumlah saham ini dikenal dengan pembagian laba per lembar saham (Earning per share /EPS). Earning per share merupakan tingkat keuntungan bersih yang mampu diraih oleh perusahaan pada saat menjalankan operasinya.

Pembagian laba atau dividen akan dibagikan apabila perusahaan memperoleh keuntungan. Keuntungan yang layak dibagikan kepada pemegang saham adalah keuntungan setelah perusahaan memenuhi seluruh kewajiban bunga dan pajak. Oleh karena itu dividen diambil dari keuntungan bersih yang diperoleh perusahaan, maka keuntungan tentu saja akan mempengaruhi besarnya dividen. Sedangkan menurut Mutamimah dan Sulistyo (2002) menyatakan bahwa EPS tidak signifikan mempengaruhi 
dividend per share pada periode 1996. Elizabeth (2000) meneliti hubungan laba akuntansi dan laba tunai dengan dividen kas dan hasilnya bahwa laba memiliki hubungan secara positif dengan dividen.

Arus kas bebas memiliki peran penting dalam pembayaran dividen di bandingkan laba bersih yang diperoleh perusahaan. Pasternak (2007:1) menyatakan "Forget earnings. If you really want to see if a company's dividend is secure, then you need to evaluate the real bottom line-free cash flow $(F C F)$ ". Ini mengindikasikan meskipun perusahaan memiliki laba dalam aktivitasnya, namun tersedianya arus kas bebas lebih menjamin agar dividen dapat dibayarkan.

Arus kas bebas merupakan arus kas yang digunakan bukan untuk membiayai hal-hal yang berhubungan dengan pembiayaan perusahaan melainkan diperuntukkan seperti biaya bunga dan dividen "Free cash flow requires that cash flow does not incorporate any financing-related cash flows, such as interest expense or dividends (Dimitrios, 2004 : 649)". Arus kas bebas selain digunakan untuk membayar dividen juga digunakan manajemen untuk melunasi hutang dan membeli kembali saham yang beredar Lebih lanjut Pasternak (2007:1) menyatakan "By contrast, free cash flow represents real money. It's the hard cash the company puts in the pocket after paying its bills and investing in the business. Management can use free cash flow to pay down debt, buy back shares, or do what's most important to income investors-pay us our dividends".

Penelitian untuk mengetahui hubungan arus kas bebas dilakukan oleh beberapa peneliti. Arfan (2006) meneliti pengaruh arus kas bebas terhadap manajemen laba, dimana tidak ada pengaruh arus kas bebas terhadap manajemen laba. Surya (2007) meneliti pengaruh arus kas bebas terhadap dividen kas, hasil penelitiannya menujukkan adanya pengaruh negatif arus kas bebas terhadap dividen kas.

Dividen merupakan hasil yang diperoleh dari saham yang dimiliki. Pengumuman dividen merupakan salah satu informasi yang akan direspon oleh pasar. Menurut Hermi (2004), pengumuman dividen dan pengumuman laba pada periode sebelumnya adalah dua jenis pengumuman yang paling sering digunakan oleh para manajer untuk menginformasikan prestasi dan prospek perusahaan.

Menurut Pasternak (2007) mengemukakan bahwa informasi yang diberikan pada saat pengumuman dividen lebih berarti daripada pengumuman earning. Bagi para investor selain capital gain yang didapat apabila harga jual saham lebih tinggi dibanding harga belinya. Dividen tersebut didapat dari perusahaan sebagai distribusi yang dihasilkan dari operasi perusahaan.

Sant (1994) menunjukkan bukti bahwa stabilitas dividen dan earning merupakan variabel yang penting yang mempengaruhi preferensi investor untuk memperoleh dividen di masa yang akan datang pada level signifikansi 0,001 (kurang dari 1\%). Ini mengindikasikan bahwa pembayaran dividen kas sebelumnya menjadi pertimbangan bagi perusahaan maupun pemegang saham.

Berdasarkan kerangka teoritis yang dikembangkan, maka dikembangkanlah skema kerangka teoritis penelitian ini, skema kerangka teoritis merupakan pola hubungan antara variable bebas (independen) dengan variable terikat (dependen) dapat dilihat pada gambar 2.1.

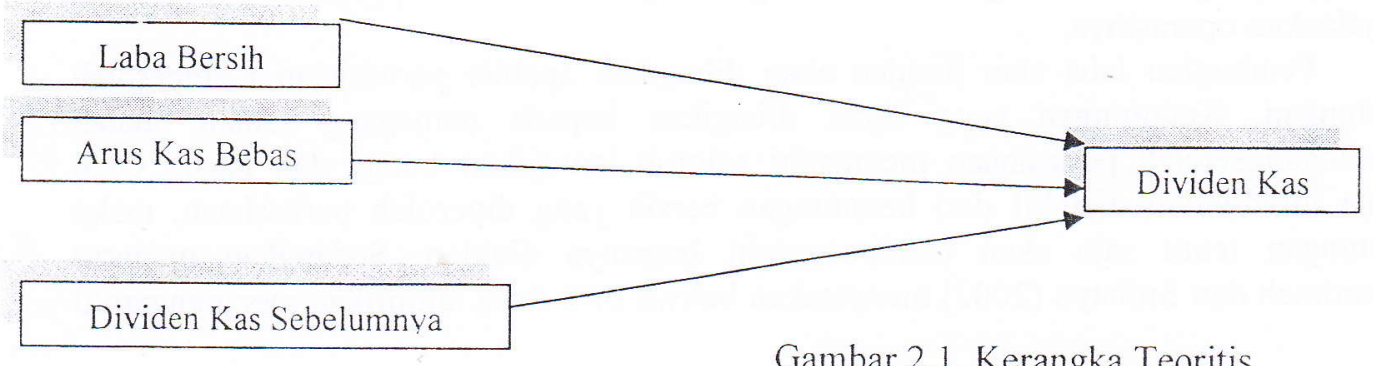

Gambar 2.1. Kerangka Teoritis 
Berdasarkan kerangka teoritis yang telah dikemukakan sebelumnya, hipotesis penelitian ini dapat dirumuskan sebagai berikut: laba, arus kas bebas, dan dividen kas sebelumnya, baik secara parsial maupun secara simultan berpengaruh terhadap dividen kas pada emiten manufaktur di Bursa Efek Indonesia.

\section{Metode Penelitian}

Penelitian ini difokuskan untuk menguji pengaruh earnings, arus kas bebas dan dividen sebelumnya terhadap dividen kas yang diperoleh para pemegang saham pada perusahaan manufaktur yang terdaftar di Bursa Efek Indonesia (BEI), dengan periode penelitian dari tahun 2002 sampai dengan 2006.

Penelitian ini bertujuan untuk menguji pengaruh variabel independen (earnings, arus kas operasi, arus kas bebas dan dividen sebelumnya) terhadap variabel dependen (dividen kas) melalui pengujian hipotesis. Sesuai dengan tujuan penelitian, maka jenis desain penelitian yang digunakan dalam penelitian ini adalah desain kausal. Desain kausal berguna untuk mengukur hubungan-hubungan antar variabel penelitian atau berguna untuk menganalisis bagaimana suatu variabel memengaruhi variabel lain (Umar, 2008:8). Metode penelitian yang digunakan adalah metode sensus, dimana semua elemen populasi diteliti. Adapun populasi sasaran dalam penelitian ini berjumlah 109 observasi.

Populasi penelitian ini adalah seluruh emiten manufaktur yang terdaftar di Bursa Efek Indonesia (BEI). Adapun yang menjadi populasi sasaran penelitian ini adalah emiten manufaktur yang terdaftar di Bursa Efek Indonesia dalam kurun waktu tahun 2002- tahun 2006 yang memenuhi kriteria.

Tabel 1

Penentuan Populasi Sasaran Emiten Manufaktur Periode 2002 sampai dengan 2006

Emiten manufaktur terdaftar di BEI

Dikeluarkan: Emiten manufaktur yang di-delist

Emiten manufaktur yang tidak di-delist.

Dikeluarkan: Emiten manufaktur yang mengalami kerugian

Emiten manufaktur yang memperoleh laba

Dikeluarkan: Emiten Manufaktur memiliki arus kas operasi negatif

Emiten Manufaktur memiliki arus kas operasi positif

Dikeluarkan: emiten manufaktur memiliki arus kas bebas negatif

Emiten manufaktur memiliki arus kas bebas positif

Dikeluarkan: emiten manufaktur tidak membayar dividen kas sebelumnya

Emiten manufaktur membayar dividen kas sebelumnya

Dikeluarkan: emiten manufaktur tidak membayar dividen kas

Emiten manufaktur membayar dividen kas
119 emiten

19 emiten

90 emiten

17 emiten

73 emiten

13 emiten

60 emiten

11 emiten

49 emiten

19 emiten

30 emiten

17 emiten 13 emiten

Sumber: Data hasil penelitian dari tahun 2002 sampai dengan 2006 (diolah).

Data yang digunakan dalam penelitian ini merupakan data sekunder dan diambil dari laporan keuangan perusahaan-perusahaan manufaktur yang terdaftar di Bursa Efek Indonesia (BEI) dari tahun 2002 sampai dengan 2006. sumber data penelitian ini adalah:

a. Mailis online Indonesia Stock Exchange (http//www.isx.co.id.)

b. Pusat Referensi Pasar Modal (Capital Market Reference Center)

c. Directory Bursa Efek Indonesia (BEI)

d. Indonesian Capital Market Directory.

e. Homepage BEI dan Pojok BEI

Data penelitian yang telah diperoleh dan dikumpulkan, kemudian diolah dengan menggunakan pooled data yaitu kombinasi antara cross sectional dan time series data (Gujarati, 1997:212) 
Tabel 2

Operasionalisasi variabel

\begin{tabular}{|c|c|c|c|c|}
\hline Variabel & Definisi & Indikator & Skala & $\begin{array}{l}\text { Referensi } \\
\text { Indikator }\end{array}$ \\
\hline $\begin{array}{c}\text { Laba } \\
\text { bersih/Net } \\
\text { Income }\left(\mathrm{X}_{1}\right)\end{array}$ & $\begin{array}{lr}\text { net income } & \text { merupakan } \\
\text { pengurangan } & \text { beban } \\
\text { (kerugian) } & \text { terhadap } \\
\text { pendapatan } & \text { (keuntungan) } \\
\text { dari semua sumber. }\end{array}$ & $\begin{array}{lr}\text { seluruh } & \text { pendapatan } \\
\text { dikurangi seluruh biaya } \\
\text { dan beban } & \text { pada } \\
\text { periode } & \text { tertentu. } \\
\text { Diukur dengan laba } \\
\text { bersih } \\
\text { saham. perlembar }\end{array}$ & Rasio & Wallace (1997) \\
\hline $\begin{array}{c}\text { Arus kas } \\
\text { Bebas }\left(\mathrm{X}_{2}\right)\end{array}$ & $\begin{array}{lr}\text { Kas yang tersedia untuk } \\
\text { didistribusikan kepada } \\
\text { pemegang saham setelah } \\
\text { semua proyek investasi } \\
\text { yang menguntungkan telah } \\
\begin{array}{l}\text { dilakukan } \\
\text { mempertahankan } \\
\text { kelanjuatan } \\
\text { perusahaan. }\end{array} \\
\end{array}$ & $\begin{array}{l}\text { Arus kas bebas. Diukur } \\
\text { dengan arus kas bebas } \\
\text { perlembar saham }\end{array}$ & Rasio & $\begin{array}{l}\text { Jones dan } \\
\text { Sarma, (2001) }\end{array}$ \\
\hline $\begin{array}{l}\text { Dividen kas } \\
\text { Sebelumnya } \\
\qquad\left(\mathrm{X}_{3}\right)\end{array}$ & $\begin{array}{lr}\text { pembayaran } & \text { dividen } \\
\text { sebelumnya } & \text { menjadi } \\
\text { pertimbangan } & \text { baik } \\
\text { perusahaan } & \text { maupun } \\
\text { pemegang saham } & \\
\end{array}$ & $\begin{array}{l}\text { dividen sebelumnya } \\
\text { diukur dengan dividen } \\
\text { per lembar. }\end{array}$ & Rasio & Penman, (2001) \\
\hline $\begin{array}{c}\text { Dividen kas } \\
(\mathrm{Y})\end{array}$ & $\begin{array}{lr}\text { dividen yang dibayarkan } \\
\text { secara tunai } & \text { oleh } \\
\text { perusahaan } & \text { kepada } \\
\text { pemegang saham } & \\
\end{array}$ & $\begin{array}{l}\text { dividen kas diukur } \\
\text { dengan dividen per } \\
\text { lembar saham. }\end{array}$ & Rasio & $\begin{array}{l}\text { Warren and } \\
\text { Reeve, (2004) }\end{array}$ \\
\hline
\end{tabular}

Data Penelitian dianalisis dengan menggunakan model analisis regresi linear berganda yaitu menggunakan pooled data mulai dari tahun 2002 sampai dengan tahun 2006. Data diolah dengan menggunakan program bantuan SPSS (Statistical Package for Social Sciences) Versi 15.0.

Adapun persamaan model regresi berganda dalam penelitian ini dapat diformulasikan sebagai berikut:

$$
Y=\beta_{0}+\beta_{1} x_{1}+\beta_{2} x_{2}+\beta_{3} x_{3}+\varepsilon
$$

Keterangan:

$$
\begin{aligned}
& \mathrm{Y}=\text { Dividen kas } \\
& \mathrm{X}_{1}=\text { Laba } \\
& \mathrm{X}_{2}=\text { Arus kas bebas } \\
& \mathrm{X}_{3}=\text { Dividen kas sebelumnya }
\end{aligned}
$$

$\beta_{0}, \beta_{1}, \beta_{2}, \beta_{3}=$ Konstanta dan koefisien regresi

$\varepsilon=$ Variabel gangguan yang tidak dimasukkan dalam model penelitian ini.

Persamaan regresi linier berganda ini digunakan untuk menguji secara parsial maupun simultan variabel independen $X_{1}, X_{2}$ dan $X_{3}$ (laba, arus kas bebas, dividen kas sebelumnya) terhadap varibel dependen $\mathrm{Y}$ (dividen kas). Model analisis data yang digunakan adalah model Regresi Linear berganda dengan menggunakan pooled data dengan tahun penelitian di mulai dari tahun 2002 sampai dengan tahun 2006.

\section{Hasil Penelitian dan Pembahasan}


Tabel 3

Descriptive Statistics

\begin{tabular}{|l|r|r|r|}
\hline & \multicolumn{1}{|c|}{ Mean } & \multicolumn{1}{c|}{ Std. Deviation } & \multicolumn{1}{c|}{ N } \\
\hline Dividen Kas & 650,0818 & $1.117,46406$ & 13 \\
Laba Bersih & $1.416,6253$ & $1.685,16013$ & 13 \\
Arus Kas Bebas & $2.430,4457$ & $2.897,53795$ & 13 \\
Pembayaran Dividen Sebelumnya & 647,6977 & $1.154,70490$ & 13 \\
\hline
\end{tabular}

Sumber : Data Sekunder Penelitian, 2007 (diolah)

Tabel 3 statistik deskriptif di atas menunjukkan bahwa dividen kas memiliki rata-rata hitung sebesar Rp. 650,08 selama lima tahun dari periode tahun 2002-2006 yang bermakna bahwa secara keseluruhan perusahaan manufaktur yang terdaftar di Bursa Efek Indonesia membayarkan dividen kas rata-rata sebesar Rp. 650,08 perlembar sahamnya

Untuk variabel laba bersih ternyata perusahaan manufaktur selama lima tahun dari kurun waktu 2002-2006 memiliki laba rata-rata perlembar saham Rp. 1.416,63 dan arus kas bebas perusahaan perlembar saham pada kurun waktu tersebut Rp. 2.430,45, juga pembayaran dividen kas perlembar sebelumnya memiliki rata-rata sebesar Rp. 647,70

Sementara standar deviasi perlembar saham yang diperoleh dari hasil uji statistik adalah untuk dividen kas Rp. 1.117,46, laba bersih Rp. 1.685,16, sementara arus kas bebas Rp. 2.897,54 dan pembayaran dividen kas sebelumnya Rp. 1.154,71.

Uji parsial adalah uji yang dilakukan untuk melihat pengaruh individual masingmasing variabel independen $(\mathrm{X})$ terhadap variabel dependen $(\mathrm{Y})$. Hasil olah data menggunakan SPSS Versi 15 menunjukkan bahwa laba bersih kurang memiliki pengaruh signifikan terhadap dividen $\mathrm{kas}$ dengan nilai $\mathrm{t}=2,011$ dengan signikansi $7,9 \%$. Sementara arus kas bebas kurang memiliki pengaruh yang signifikan terhadap dividen kas dengan nilai $\mathrm{t}=0,205$ dan signifikansi $84,3 \%$ karena tingkat signifikansi yang ada diatas kurang dari $95 \%$. dan pembayaran dividen kas sebelumnya memiliki pengaruh signifikan terhadap dividen kas dengan nilai $\mathrm{t}=31,613$ dengan signifikansi lebih kecil dari $5 \%$ yaitu 0,000 pada emiten manufaktur yang terdaftar di Bursa Efek Indonesia (BEI).

Tabel 4.

Coefficients

\begin{tabular}{|c|c|c|c|c|}
\hline \multicolumn{2}{|c|}{ Mode } & $\begin{array}{l}\text { Standardized } \\
\text { Coefficients }\end{array}$ & $\mathrm{T}$ & \multirow[t]{2}{*}{ Sig. } \\
\hline & & Beta & & \\
\hline \multirow[t]{4}{*}{1} & (Constant) & 0,129 & 0,180 & 0,862 \\
\hline & Laba Bersih & $-0,113$ & 2,011 & 0,079 \\
\hline & Arus Kas Bebas & 0,976 & 0,205 & 0,843 \\
\hline & $\begin{array}{l}\text { Pembayaran Dividen } \\
\text { Sebelumnya }\end{array}$ & 0,129 & 31,613 & 0,000 \\
\hline
\end{tabular}

a. Dependen Variable: Dividen Kas

Uji simultan Sumber: Data Primer Penelitian, 2007 pengaruh variabel independen $(X)$ secara versania-sana unamap vanaues ucponucu ( $Y$ ). Hasil uji $F$ ini dapat dilihat pada tabel Anova atau tabel 4.5. berikut: 
ANOVA(b)

\begin{tabular}{|ll|r|r|r|r|}
\hline Model & & Df & Mean Square & F & Sig. \\
\hline 1 & Regression & 4 & $3.740 .384,248$ & $1.291,228$ & $.000(\mathrm{a})$ \\
& Residual & 8 & $2.896,766$ & & \\
& Total & 12 & & & \\
\end{tabular}

a. Predictors: (Constant), Dividen Kas Sebelumnya, Arus Kas Operasi, Laba Bersih, Arus Kas Bebas

b. Dependent Variable: Dividen Kas

Dari hasil pengolahan data dapat dilihat nilai $F_{\text {hitung }}$ sebesar 1.291,228 dengan tingkat signifikansi sebesar 0,000 $(0,000<0,05)$ berarti hipotesis $\mathrm{H}_{\mathrm{a}}$ diterima, bermakna, laba bersih, arus kas bebas, dan dividen kas sebelumnya secara simultan berpengaruh terhadap dividen kas pada emiten manufaktur di Bursa Efek Indonesia. Sebaliknya hipotesis $\mathrm{H}_{0}$ yang menyatakan laba bersih, arus kas bebas, dan dividen kas sebelumnya secara simultan tidak berpengaruh terhadap dividen kas pada emiten manufaktur di Bursa Efek Indonesia, ditolak.

Berdasarkan pengolahan data maka diperoleh model persamaan dari laba bersih, arus kas bebas, dan dividen kas sebelumnya secara simultan berpengaruh terhadap dividen kas pada emiten manufaktur di Bursa Efek Indonesia, tabel 4.6 coeficients berikut menggambarkan persamaan regresi linear berganda:

Tabel 5

Coeficients

\begin{tabular}{|c|c|c|c|c|c|}
\hline \multirow[t]{2}{*}{ Model } & & \multicolumn{2}{|c|}{$\begin{array}{l}\text { Unstandardized } \\
\text { Coefficients }\end{array}$} & \multirow[t]{2}{*}{$\mathrm{t}$} & \multirow[t]{2}{*}{ Sig. } \\
\hline & & $\mathrm{B}$ & $\begin{array}{l}\text { Std. } \\
\text { Error }\end{array}$ & & \\
\hline \multirow[t]{4}{*}{1} & (Constant) & 4,088 & 0,180 & 0,180 & 0,862 \\
\hline & Laba Bersih & 0,086 & 2,011 & 2,011 & 0,079 \\
\hline & Arus Kas Bebas & 0,011 & 0,205 & 0,205 & 0,843 \\
\hline & $\begin{array}{l}\text { Pembayaran Dividen } \\
\text { Sebelumnya }\end{array}$ & 0,944 & 31,613 & 31,613 & 0,000 \\
\hline
\end{tabular}

a. Dependent Variable: Dividen Kas

$Y=4,088+0,086 X_{1}+0,011 X_{2}+0,944 X_{3}$

Berdasarkan persamaan di atas dapat dijelaskan bahwa, koefisien dan variabel laba bersih adalah $\beta_{1}=0,086$ yang berarti setiap kenaikan variabel laba bersih sebesar 1 maka dividen kas akan naik sebesar 8,6\% dengan asumsi variabel lain tetap. Variabel laba bersih mempunyai nilai sig.t $=0,079$. Ini berarti secara parsial hubungan variabel laba bersih kurang berpengaruh secara signifikan terhadap variabel dividen kas.

Variabel arus kas bebas menghasilkan koefisien $\beta_{3}=-, 011$ yang berarti setiap kenaikan variabel arus kas bebas sebesar 1 maka dividen kas akan turun sebesar 1,1\% dengan asumsi variabel lain tetap. Variabel arus kas bebas mempunyai nilai sig.t $=0,843$. Ini berarti secara parsial hubungan variabel arus kas bebas kurang berpengaruh secara signifikan terhadap variabel dividen kas.

Variabel dividen kas sebelumnya menghasilkan koefisien $\beta_{4}=0,944$ yang berarti setiap kenaikan variabel dividen kas sebesar 1 maka dividen kas akan meningkat sebesar 94,4\% dengan asumsi variabel lain tetap. Variabel dividen kas sebelumnya mempunyai nilai sig.t $=0,000$. Ini berarti secara parsial hubungan variabei pembayaran dividen kas sebelumnya terhadap variabel dividen kas berpengaruh secara signifikan. 


\section{Simpulan}

Penelitian ini ditujukan untuk menguji dan menganalisis pengaruh laba, arus kas bebas, dan dividen kas sebelumnya terhadap dividen kas pada emiten manufaktur yang terdaftar di Bursa Efek Jakarta. Hipotesis diuji dengan menggunakan regresi berganda (multiple regression) dengan model empiris. Hasil penelitian menunjukkan bahwa laba bersih, dan arus kas bebas dan dividen kas sebelumnya secara bersama-sama atau simultan berpengaruh signifikan positif terhadap dividen kas pada emiten manufaktur di Bursa Efek Jakarta.

Secara parsial, laba bersih, dan arus kas bebas kurang memiliki pengaruh yang sinifikan terhadap dividen kas. Namun untuk pembayaran dividen kas`sebelumnya sangat berpengaruh signifikan positif terhadap dividen kas pada emiten manufaktur di Bursa Efek Jakarta.

\section{Keterbatasan Penelitian}

Penelitian ini memiliki keterbatasan sehingga menimbulkan masih adanya variabel yang kurang memiliki pengaruh signifikan terhadap dividen kas, keterbatasan ini dapat saja dikarenakan:

a. Terbatasnya sampel yang digunakan hanya pada perusahaan manufaktur.

b. Berdasarkan data yang ditemukan, masih adanya perusahaan manufaktur yang belum melaporkan laporan keuangan auditannya sesuai tahun berjalannya.

c. Masih adanya hasil olah data SPSS Versi 15 seperti variabel arus kas bebas yang hasil olah datanya kurang signifikan dan arus kas operasi yang signifikansinya negatif

d. Mungkin juga, keterbatasan disebabkan terlalu ketatnya kriteria sampel yang digunakan, sehingga hanya 13 sampel yang diperoleh dari 119 perusahaan manufaktur yang terdaftar di BEI.

Saran

Dari kesimpulan dan keterbatasan penelitian yang dihasilkan, dapat disarankan:

a. Perlunya mempertimbangkan memperbesar jumlah sampel penelitian dengan cara: memasukkan jenis perusahaan lain diluar perusahaan manufaktur, maupun dengan menambah jumlah sampel dengan memperpanjang jangka waktu penelitian.

b. Ada baiknya Bapepam lebih bersikap tegas lagi bagi emiten yang listing di BEI untuk secara rutin dan tepat waktu melaporkan kondisi keuangannya setiap tahun, hal ini selain berguna bagi kredibilitas emiten itu sendiri, kredibilitas Bapepam dan BEI, juga terinformasikannya secara kontinue kondisi perusahaan bagi investor selain berguna bagi perkembangan riset permodalan dan investasi di pasar modal.

c. Penelitian berikutnya perlu mempertimbangkan alternatif varabel lain, selain arus kas operasi dan arus kas bebas agar hasil yang diperoleh lebih baik.

d. Kriteria sampel yang ditetapkan dalam pemilihan sampel perlu dilakukan peninjauan ulang dengan apakah memperlonggar kriteria sampel ataupun lebih memperketat kriteria sampel tersebut.

\section{Daftar Pustaka}

Aida Yulia, dan Muslim A. Jalil, (2003), Pengaruh Orientasi Profesional Terhadap Konplik Peran: Interaksi antara partisipasi anggaran dan penggunaan anggaran sebagai alat ukur kinerja dengan orientasi manajemen. Jurnal Telaah \& Riset Akuntansi Vol. 1 No. 3 Desember 2003

Ainul M, Aida dan Gudono, (2001), Pengaruh Ketidakpastian Lingkungan dan Desentralisasi Terhadap Karakteristik Informasi Sistem Akuntansi Manajemen. Jurnal Riset Akuntansi Indonesia. Vol. 4. No. 1 Januari 2001. 
Arfan, Muhammad (2006). Pengaruh Arus Kas Bebas, Set Kesempatan Investasi, Dan Financial Leverage Terhadap Manajemen Laba. Desertasi, Universitas Padjadjaran.

Belkaoui, Ahmed (1993). Accounting Theory. Third Edition, Orlando Florida, Harcoult \& Brace Corporation.

Bodie, Zvi (1998). Essentials of Investment. Third Edition, New York, Irwin Mc GrawHill.

Brealey, Myers, and Allen (2006). Corporate Finance. Eight Edition. New York, Irwin Mc Graw-Hill.

Brigham, Eugene F. dan Philip R Daves. 2004. Intemediate Finacial Management. 8th Edition. Mason, Ohio: South-Western.

Copeland, T., Koller, T. and Murrin, J. (1991), Valuation: Measuring and Managing the Value of Companies, McKinsey \& Company, Inc.

Dimitrios V. Kousenidis (2004). A free cash flow version of the cash flow statement: a Note. School of Economics, Department of Business Administration, Aristotle University of Thessaloniki, Greece

Elizabeth (2000). Hubungan Laba Akuntansi, Laba Tunai dengan Dividen Kas. Tesis, Universitas Indonesia.

Financial Accounting Standard Board (1990). Statement of Financial Accounting Concepts, Illinois 60430: Irwin Homewood.

Fitriastuti, Lucia Ika (2004). "Analisis Kemampuan Prediksi Laba, Komponen Laba, Dan Arus Kas Untuk Memprediksi Arus Kas Masa Depan: Studi Pada Perusahaan Manufaktur Di BEJ ". Tesis, Universitas Gajah Mada.

Fridson, Martin S. (1995). Financial Statement Analysis. $2^{\text {nd }}$ ed. New York : John Wiley and Sons, Inc.

Gujarati, D.N. (1995). Basic Econometric. Singapore: Mc Graw-Hill Company.

Gunawan, Endra (2007). "Pengaruh Cash Ratio, Current Ratio, Total Debt To Total Asset, Laba Akuntansi dan Laba Tunai Terhadap Dividen Kas Pada Perusahaan Manufaktur Di Bursa Efek Jakarta 2001-2005." Tesis, Universitas Syiah Kuala.

Hartono,Jogianto (1998). Teori Portofolio dan analsis Investasi .Edisi Empat. Jakarta: Penerbit Salemba Empat.

Hendriksen, Eldon S. dan Michael F, Van Breda (1992). Accounting Theory. Fifth Edition Boston : Richard D. Irwin, Inc.

Hermi (2004)."Hubungan Laba Bersih Dan Arus Kas Operasi Terhadap Deviden Kas". Tesis, Universitas Trisakti.

Ikatan Akuntan Indonesia (2007). Standard Akuntansi Keuangan. Jakarta : Penerbit Salemba Empat.

Imam Ghozali (2001), Aplikasi Analisis Multivariate dengan Program SPSS, BP Undip, Semarang.

Jones, Stewart dan Rohit Sarma (2001). The Impact Of Free cash Flow, Finacial Leverage and Accounting Regulation on Earnings Management in Australia's Old and New Economies. Managerial Finance, Vol 27, No.12, pp.18-39.

Kieso, Donald E dan Jerry J Weygandt (1998). Intermediate Accounting. Ninth Edition. New York: John \& Sons, Inc

Lipe,R.C.(1990). "The Relationship Between Stock Return And Accounting Earnings Given Alternative Information". Contemporary Accounting Research 69: 49-71.

Lintner, J. (1956), "Distribution of Incomes of Corporations Among Dividends, Retained Earnings and Taxes", American Economic Review, Vol. 46, pp. 97-113.

Meythi (2003). "Pengaruh Arus Kas Operasi Terhadap Harga Saham Dengan Persistensi Laba Sebagai Variabel Intervening". Tesis, Univesitas Kristen Maranatha. 
Mutamimah dan Sulistyo. (2000)." Analisis Faktor- Faktor yang mempengaruhi Dividen Per Share Perusahaan-Perusahaan yang Go Public di Bursa Efek Jakarta". Yogyakarta

Naimah, Zahroh dan Sidharta Utama (2005). "Pengaruh Ukuran Perusahaan, Pertumbuhan, Dan Profitabilitas Perusahaan Terhadap Koefisien Respon Laba dan Koefisien Respon Nilai Buku Ekuitas: Studi Pada Perusahaan Manufaktur Di Bursa Efek Jakarta". Tesis, Universitas Kristen Maranatha.

Niswonger, Rollin. Philip E.Fess and Carl S. Warren (1993). Prinsip-Prinsip Akuntansi. Edisi Keenam belas, Alih Bahasa Oleh Hyginus Ruswinarto dan Herman Wibowo, Jakarta: Penerbit Erlangga.

Nurhidayati (2006). "Analisis Faktor-Faktor Yang Mempengaruhi Dividen Kas Di Bursa Efek Jakarta." Skripsi, Universitas Islam Indonesia, Yokyakarta.

Pasternak (2007). Free Cash Flow For Dividen Payment. http//:www.themotleeyfool@yahoo.co.id.

Penman, Steven H. (2001). Financial Statement Analisys Security Valuation. Singapore: Mc Graw Hill

Sant, R. and Cowan, A.R. (1994), "Do dividends signal earnings? The case of omitted dividends", Journal of Banking and Finance, Vol. 18, pp. 1113-33.

Scroeder, Richard G. dan Myrtle Clark (1998). Accounting Theory-Text and Reading. $6^{\text {th }}$ Edition. Canada : John Willey \& Sons, Inc.

Smith, Jay M. dan K. Fred Skousen (1997). Intermediate Accounting. 12 $2^{\text {th }}$ Edition Cincinati : South Western Publishing.

Suharli, Michelle (2006). 'Pengaruh Profitability Dan Investment Opportunity Set Terhadap Kebijakan Dividen Tunai Dengan Likuiditas Sebagai Variabel Penguat: (Studi Pada Perusahaan Yang Terdaftar Manufaktur Di BEJ 2002-2003).” Tesis Magister Akuntansi (Tidak Dipublikasikan). Jakarta.

Suadi, Arief (1998). Penelitian Tentang Manfaat Laporan Keuangan. Jurnal Ekonomi dan Bisnis Indonesia Vol 13. N0.2: 1-16.

Surya, Jen (2007). "Pengaruh Laba, Arus Kas Operasi, dan Arus Kas Bebas Terhadap Dividen Kas Pada Perusahaan Manufaktur Di Bursa Efek Jakarta 2001-2005." Tesis Universitas Syiah Kuala.

Susanto, San dan Erni Ekawati (2004). "Relevansi Nilai Informasi Laba Dan Aliran Kas Terhadap Harga Saham Dalam Kaitannya Dengan Siklus Hidup Perusahaan". Tesis, Universitas Kristen Duta Wacana.

Swasta, Basu (1997). Pengantar Ekonomi Perusahaan Modern. Edisi Revisi, Harcou Yogyakarta, Penerbit Liberty.

Thiono, Handri (2005). "Perbandingan Keakuratan Model Arus Kas Metode Langsung Dan Tidak Langsung Dalam Memprediksi Arus Kas Dan Deviden Masa Depan”. Tesis, Universitas Gajah Mada.

Umar, Husein (2008), Desain Penelitian Akuntansi Keperilakuan. Jakarta, PT Raja Grafindo Persada

Wallace, Wanda A. (1997). Financial Accounting. $3^{\text {rd }}$ ed. Cincinati : South Western Publishing.

Warren and Reeve (2004). Financial Accounting for Future Business Leaders. Cincinati : South Western Publishing.

Yahya, Muhammad Nur (2005) "Tingkat Keuntungan Dan Likuiditas Saham Disekitar IPO Dengan Ukuran Perusahaan Sebagai Variabel Kontrol". Tesis, Universitas Syiah Kuala. 